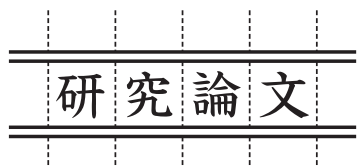

マイクロフレームを用いたウェットバイオガスの微小スケールでの燃焼安定性

\title{
Flame Stabilization on Microscopic Scale of Wet Biogas with Microflame
}

\author{
井田民男*・渕端学* ・水野 諭* \\ Tamio IDA, Manabu FUCHIHATA and Satoru MIZUNO
}

(Received June 7, 2010)

\begin{abstract}
Harvesting, transportation, energy conversion and the high-efficient utilization, cascade method and market formation besides become with the indispensable element in order to utilize the biomass resource. There are two type biogases; it is gasified gas from dried biomass by partially combustion and wet biogas from wet biomass by methane fermentation, especially from the livestock excrement resources. This paper discusses an experimental study for flame stabilization on microscopic scale with wet biogas (mainly $0.6 \mathrm{CH}_{4}+0.4 \mathrm{CO}_{2}$ ). In this study, the microflame with the wet biogas fuels are formed by the diffusion flame on the coppered straight pipes of inner diameter $0.02 \mathrm{~mm} \sim 1.5 \mathrm{~mm}$. This study is obtained stability mapping on microscopic scale of formed microflame by wet biogas fuels. The flame stability limit conditions on microscopic scale of wet biogas is drawn with blow off and extinction flame double limit lines. It is suggested that minimum mixing spatial scale change by the each mixing ratio of the wet biogas.
\end{abstract}

Key Words: Microscopic Scale, Combustion Stabilization, Microflame, Wet Biogas

\section{1. 緒言}

バイオマス資源を活用するには、収穫から輸送、エネル ギー変換とその高効率利用、さらにカスケード利用と各ス テージでの市場成立が不可欠な要素となる。特に、エネル ギー変換ステージにおいては、バイオマス資源をガス化し 熱エネルギーとして活用する視点から見ると、炭化水素系 の混合ガスとなるので、従来の単独ガス燃焼とは異なり、 混合ガス燃焼での燃焼特性の把握が必要となる。さらに、 ドライあるいはウェットバイオマスからのガス化におい て、そのガス化条件により、混合ガスの比率が異なること は周知であり、これらの燃焼過程での安定性の向上あるい は高効率化などの基礎研究が少ないきらいがある ${ }^{1)-3)}$

本研究室では、マイクロオーダーのバーナを開発し、そ の上に定常かつきわめて小さな火炎（マイクロフレームと 呼ぶ）を形成することに成功し、拡散火炎及び予混合火炎 の微小スケールでの燃焼安定性について研究を推進してい

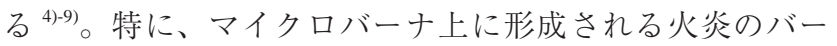
ナ出口での流体力学的な条件をパラメータにすることによ り、上限条件あるいは下限条件での燃焼安定性を定量的に 評価することが可能となった。さらに、拡散火炎での下限 スケールでは、周囲空気との混合スケールがコロモゴロフ スケールに漸近することと、定常な燃焼反応を持続するた めの熱容量が限界に近づくため、安定な燃焼反応を実現す

るための知見を得ることができる ${ }^{10), 11)}$

本研究では、ウェットバイオガスの高度な燃焼技術の開 発を鑑み、畜産污泥資源からのメタン発酵技術から作られ るウェットバイオガスに焦点を絞り、その微小スケールで のバイオガスの燃焼安定性について検討する。

\section{2. 実験方法}

実験は、微小スケールでの燃焼安定性について定量的な 評価を得るための実験を行う。ここでは、畜産污泥資源か らのメタン発酵バイオガス（主に $0.6 \mathrm{CH}_{4}+0.4 \mathrm{CO}_{2}$ ）の燃 焼安定性を得るためにTable1に示す実験条件で行った。 マイクロフレームは、内径 $0.02 \mathrm{~mm} \sim 1.5 \mathrm{~mm}$ の銅製スト レートパイプ上に拡散火炎により形成した。マイクロフ レームの観察は、定常に燃焼反応が維持できる状態を目視 により確認し、静止撮影およびバーナ出口での流体力学的 な条件をパラメータに行った。

Table 1 Mixing ratio with wet biogas

\begin{tabular}{|c|c|c|c|c|c|}
\hline No. & A1 & A2 & A3 & A4 & A5 \\
\hline $\mathrm{CH}_{4}$ (vol\%) & 60 & 70 & 80 & 90 & 100 \\
\hline $\mathrm{CO}_{2}$ (vol\%) & 40 & 30 & 20 & 10 & 0 \\
\hline
\end{tabular}

* 近畿大学理工学部（† 577-8502 東大阪市小若江 3-4-1）

School of Science and Engineering, Kinki University (3-4-1 Kowakae, Higashi-Osaka, Osaka 577-8502, Japan) 


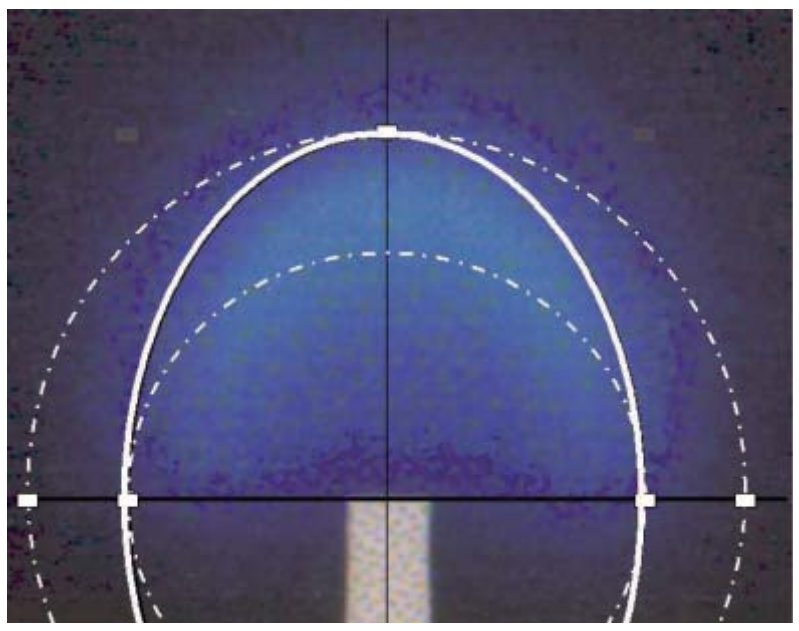

Photo.1 Typical microflame formed on $\phi 0.1 \times 0.2 \mathrm{~mm}$

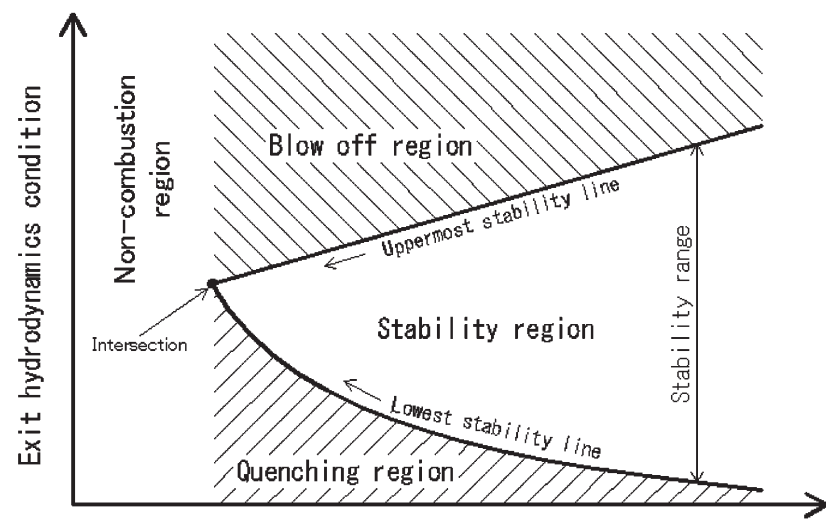

Exit burner size

Fig.1 Schematic of combustion stability region map

\section{3. 実験結果と考察}

3.1 マイクロフレームの基礎燃焼特性

マイクロフレームの基礎的な燃焼特性を示す。Photo.1 に $\phi 0.1 \times 0.2 \mathrm{~mm}$ のマイクロバーナ上に形成される 0.6 $\mathrm{CH}_{4}+0.4 \mathrm{H}_{2}$ 燃料による出口での燃料流量が下限条件での拡 散火炎の静止撮影結果を示す。火炎の高さは、青炎部の先 端で $0.8 \mathrm{~mm}$ 、火炎幅は、1.2 mm と下流方向に縦長の半楕 円球の形状をしている。青炎部は、三日月上に観察される。

Fig.1にバーナ径と出口での燃料噴出条件による燃焼安定 性のイメージを示す。このイメージは、燃料種が決まると その拡散過程、発熱量などが決まることにより、その微小 スケールでの燃焼安定性が描けることを示している。特に、 バーナ出口での燃料噴出条件が上限と下限值に挟まれた領 域で定常火炎が形成されることが分かり、バーナサイズを 小さくするに従い、その範囲が狭まりバーナサイズに対す
る下限值が求まることが分かる。このバーナサイズ以下で は、定常な火炎が形成できない領域が存在することを示す。

3.2 ウェットバイオマスガスのマイクロバーナ上に形成さ れる火炎形状

Photo.2にTable1 に基づく燃料比率の異なる条件による 火炎形状の変化を示す。写真下方に見られる白い四角がマ イクロバーナの外形と位置を表している。火炎形成条件は、 バーナ出口での下限燃料流量条件である。(a) は、 $\phi 1.5 \times 2.5$ $\mathrm{mm}$ のバーナ上に形成された撮影結果、(b) $\phi 1.0 \times 1.7 \mathrm{~mm}$ のバーナ上に形成された撮影結果、(c) $\phi 0.4 \times 0.6 \mathrm{~mm}$ の撮 影結果、(d) $\phi 0.2 \times 0.4 \mathrm{~mm}$ での撮影結果を示す。また、火 炎形状の変化を定量的に考察するために、Fig.2に(a) $\phi 1.5$ $\times 2.5 \mathrm{~mm}$ バーナサイズでの火炎高さの変化を示す。

(a)(b) は、ミリサイズバーナ上に形成される燃料比率が 異なる火炎形状の変化を示す。バーナ出口での燃料流量は、 $\pm 5 \%$ 範囲で同量の燃料供給量であるにも関わらず、火 炎形状が大きく変化している Fig.2に示す火炎高さについ ては、メタン燃料の比率が多くなるに従い、指数関数的に 小さくなり、A1/A5 条件では約 3 倍の変化が見られる。火 炎形状は、メ夕ン燃料の比率が多いほど、青炎部面積は少 なく三日月状の青炎領域が観察されるが、メタン燃料の比 率が減るほど、馬蹄状の火炎形状へと変化している。さら に、メタン燃料の比率が減るほど、青炎部での自発光強度 が弱くなる傾向にある。特に、青炎部の馬蹄形状先端での 自発光が極端に弱くなり、筒状の発光領域が形成されてい ることが分かる。

(c) マイクロバーナ上に形成される定常火炎では、A5 と A4の実験条件でのみ定常な火炎が形成できる。火炎高さは、 A4 : $0.705 \mathrm{~mm} 、 \mathrm{~A} 5 ： 0.882 \mathrm{~mm}$ と少し変化するが、火炎形 状はメタン燃料の比率が下がっているので、青炎部が馬蹄 状へと明確に変化していることが分かる。さらに、(d)では、 A5 条件でのみ定常火炎が形成される。火炎高さは $0.44 \mathrm{~mm}$ と小さく、青炎部がきわめて薄い三日月状の火炎が形成さ れる。

(a)〜 (d) の静止撮影結果を見ると、バーナからの青炎部 までの浮き上がりのような領域の高さは、下限条件下でほ ぼ一定であり、バーナ出口での噴出条件に寄らないことが 分かる。

3.3 マイクロバーナによる燃焼安定性マップ

Fig.3に Table1 の A1〜 A5 の実験条件での異なるバー ナサイズにより定常火炎が形成されるバーナ出口での上限 と下限值を指標とする噴出条件による燃焼安定性マップを 示す。図からバーナサイズと燃料混合比率の変化による安 定性の変化と特徵を得ることができる。Fig.4には、メ夕 ン混合比率に対する下限条件での極小バーナサイズの変化 を示す。

まず、バーナサイズの影響は、燃料混合比率の変化に関 


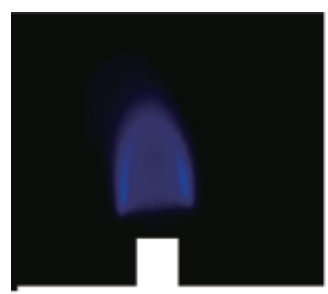

(A1)

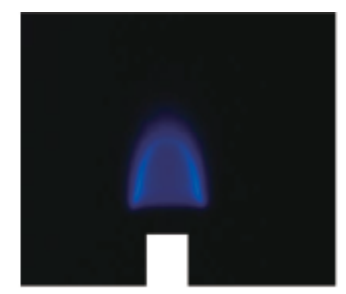

(A2)

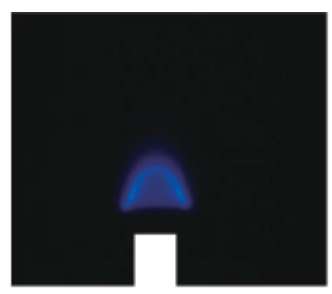

(A3)

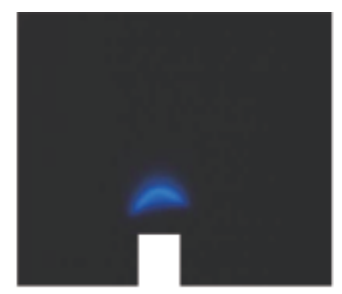

(A4)

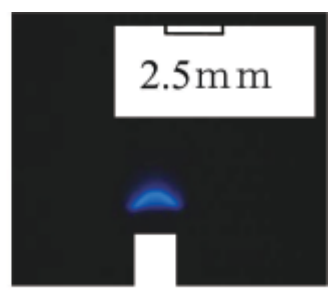

(A5)

(a) Microflame on $\phi 1.5 \times 2.5 \mathrm{~mm}$

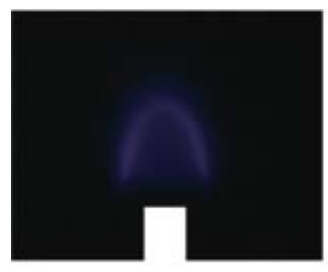

(A1)

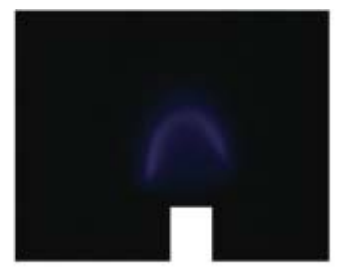

(A2)

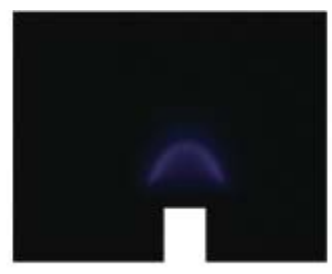

(A3)

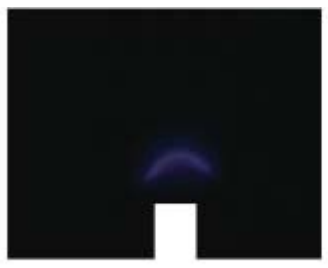

(A4)

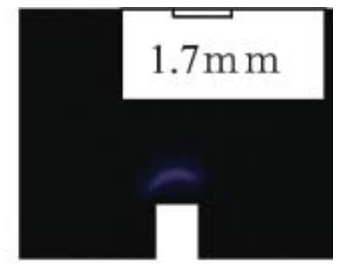

(A5)

(b) Microflame on $\phi 1.0 \times 1.7 \mathrm{~mm}$

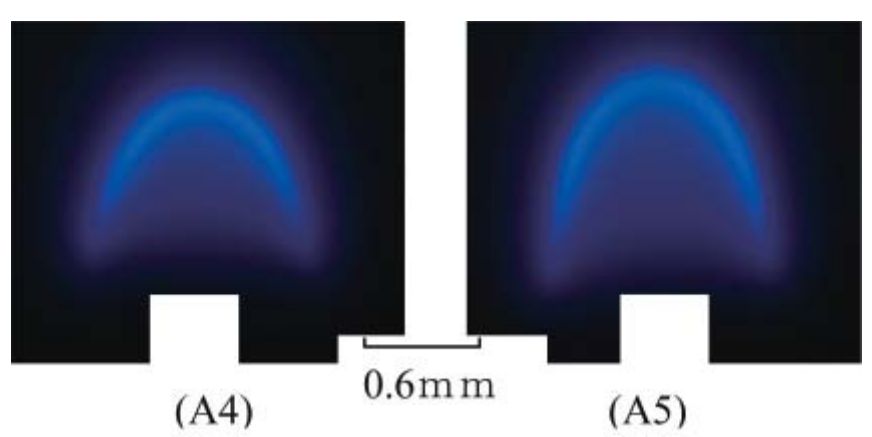

(c) Microflame on $\phi 0.4 \times 0.6 \mathrm{~mm}$

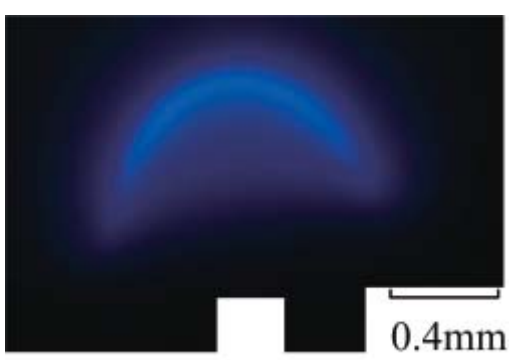

(A5)

(d) Microflame on $\phi 0.2 \times 0.4 \mathrm{~mm}$

Photo.2 Change of flame shape under lowest limit condition for various mixing ratios

わらず、定常火炎が形成できるバーナサイズに対する極小 值が存在し、その燃料流量は A1〜 A4 条件ではほぼ同量で あることが分かった。また、定常燃焼領域は、メタン燃料 の比率が減るに従いその安定領域が小さくなっていること が分かる。下限流量值に関しても、バーナサイズが変化し ても、定常火炎形成に必要な燃料流量はさほど変化しない ことが分かる。これらの結果より、混合燃料ガス燃焼の定 常火炎が形成できる下限值において、混合比率により最小 混合空間スケールが変化していることを定量的に得ること ができた。

\section{4. 結 果}

マイクロフレームを用いて、ウェットバイオマスガスの
各種混合燃料ガスの燃焼安定を実験的に求め、次のような ことが分かった。

1) 混合燃料ガスの燃焼安定性マップを描き、バーナサイズ に対する極小值を定量的に求めることができた。

2) 混合燃料ガスのメタン燃料比率が少なくなるに従い、定 常然焼領域が小さくなることが分かった。

3) 混合燃料ガスの混合比率により、最小混合空間スケール が変化し、その定量值を求めることができた。

\section{参考文献}

1) 横山伸也他 ; バイオマスハンドブック（日本エネルギー学会 編)、(2002) 152-156オーム社

2) 小宮山宏、迫田章義、松村幸彦;バイオマス・ニッポン、(2003) 
マイクロフレームを用いたウェットバイオガスの微小スケールでの燃焼安定性（井田・㴊端・水野）

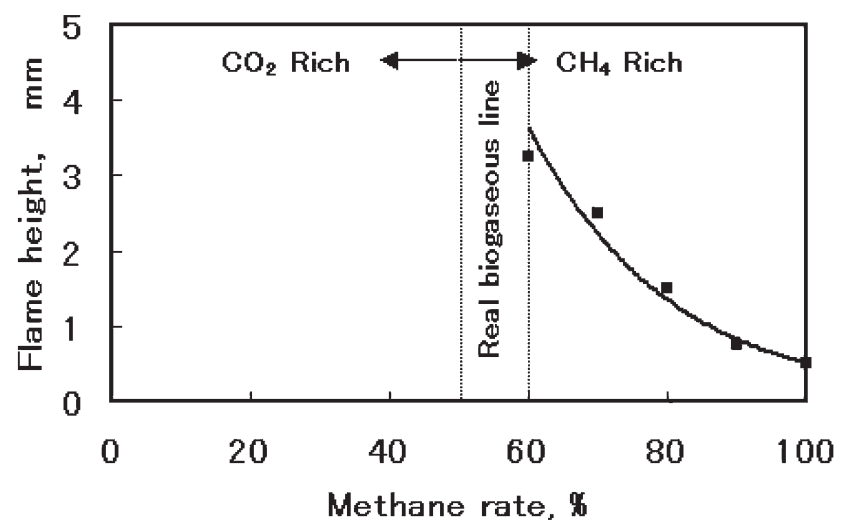

Fig.2 Change of flame height on $\phi 1.5 \times 2.5 \mathrm{~mm}$

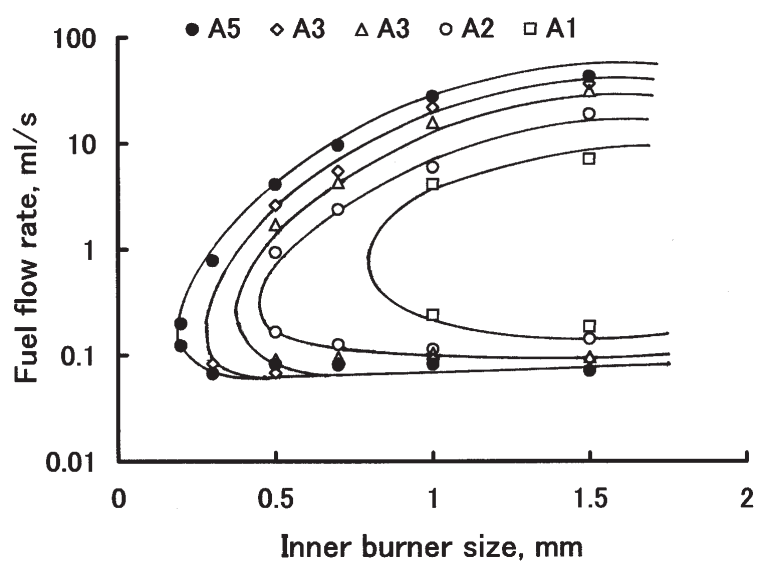

Fig.3 Combustion stability map of microflame

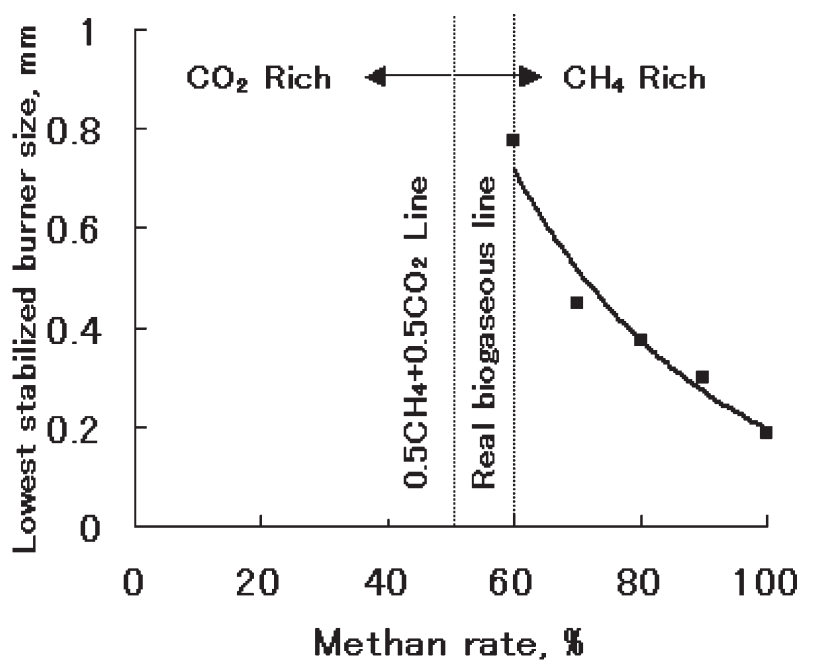

Fig.4 Change of Minimum burner size based on lowest condition
77-81 日刊工業新聞社

3）羽賀清典他；家畜排せつ物の処理・リサイクルとエネルギー 利用、(2004) 26-31 NTS

4) 湯浅裕樹他; 分子拡散に支配されるマイクロ・ジェットフレー ムの着火・消炎機構の可視化、第 40 回燃焼シンポジウム講演 論文集、(2002) 127-128

5) 中村祐二、斉藤孝三；マイクロフレームに形成される熱と流 れ場、ながれ、20(2001) 74-82

6) H. BAN, S. Venkatesh, K. Saito; Convection - Diffusion Controlled Laminar Micro Flames, Transactions of the ASME, 116, (1995), 954-959

7) 井田民男、㴊端学、水谷幸夫 ; マイクロ・ジェットフレーム の基礎燃焼特性、第 38 回燃焼シンポジウム講演論文集、(2000) 281-282

8) 井田民男、大竹一友 ; マイクロフレームツールとしての微視 的火炎構造の燃焼特性、第 34 回燃焼シンポジウム講演論文集、 (1996) 270-272

9) 井田民男、渕端学 ; 「きわめて小さな火炎」が造りだす微小領 域での火炎現象、日本燃焼学会、45-134 (2003) 1-5

10) 大竹一友、藤原俊隆 ; 燃焼工学、(1985) 69-139 コロナ社

11) 水谷幸夫 ; 燃焼工学、(1989) 76-114 森北出版社 